\title{
PENGARUH MANAGEMENT CHANGE, FINANCIAL DISTRESS, UKURAN PERUSAHAAN KLIEN, DAN OPINI AUDIT TERHADAP AUDITOR SWITCHING
}

\author{
Nurul Aini*1, M. Rizal Yahya ${ }^{* 2}$ \\ ${ }^{1,2}$ Program Studi Akuntansi Fakultas Ekonomi dan Bisnis Universitas Syiah Kuala \\ e-mail: Nnurul883@gmail.com ${ }^{* 1}$, rizal_yahya@unsyiah.ac.id ${ }^{* 2}$
}

\begin{abstract}
The research examines the effect of management change, financial distress, client's size, and audit opinion on auditor switching. The population in this research are the banking companies listed in Indonesia Stock Exchange for year of 2010-2015. The samples in this study using purposive sampling method, the number of obsevations of a sample of 84 studies. The data analysis technique used is logistic regression analysis.The result of this reasearch show that management change, financial distress, client's size and opinion audit have effect on auditor switching. Partially the research show that (1) Management change significantly influences on auditor switching, (2) financial distress do not affects on auditor switching, (3) client's size significantly influences on auditor switching, and (3) audit opinion significantly infleunces on auditor switching. .
\end{abstract}

Keywords: Management Change, Financial Distress, Client's Size, Audit Opinion, Auditor Switching.

\section{Pendahuluan}

Pembatasan masa perikatan audit adalah salah satu cara untuk mencegah auditor berinteraksi terlalu lama dengan kliennya yang dapat mengganggu independensi auditor. Oleh karena itu, dikeluarkanlah peraturan yang membatasi masa perikatan audit. Peraturan tersebut dituangkan dalam Keputusan Menteri Keuangan Republik Indonesia Nomor 17/PMK.01/2008 tentang "Jasa Akuntan Publik". Pasal 3 ayat 1 berisi tentang pemberian jasa audit umum atas laporan keuangan dari suatu entitas sebagaimana dimaksud dalam pasal 2 ayat (1) huruf a dilakukan oleh KAP (Kantor Akuntan Publik) paling lama 6 (enam) tahun buku berturut-turut dan oleh seorang Akuntan Publik paling lama untuk 3 tahun buku berturut-turut. Pasal 3 ayat 2 menyatakan bahwa

Akuntan Publik dapat menerima kembali penugasan audit umum untuk klien setelah 1 (satu) tahun buku tidak memberikan jasa audit umum atas laporan keuangan klien tersebut.Peraturan tersebut diperbaharui kembali dengan dikeluarkannya Peraturan Pemerintah Nomor 20 tahun 2015. Pasal 11 ayat 1 berisi tentang pemberian jasa audit atas informasi keuangan historis sebagaimana dimaksud dalam pasal 10 ayat (1) huruf a terhadap suatu entitas oleh seorang Akuntan Publik dibatasi paling lama untuk 5 (lima) tahun buku berturut-turut. Akuntan publik dapat memberikan kembali jasa audit atas informasi keuangan historis terhadap entitas setelah 2 (dua) tahun buku berturut-turut tidak memberikan jasa tersebut pada suatu perusahan (Astrini dan Muid, 2013).Pada PeraturanPemerintahtersebut tidak adanya pembatasan bagi KAP untuk melakukan audit pada suatu perusahaan namun, perusahaan harus mengganti akuntan publiknya sesuai dengan Peraturan Pemerintah yang telah ditetapkan.

Dampak dari berlakunya Peraturan Pemerintah tersebut adalah KAP tidak perlu membentuk KAP baru dengan perubahan nama, ataupun anggota patner untuk melakukan pergantian KAP. Auditor switching merupakan salah satu peraturan yang diwajibkan oleh pemerintah Indonesia sebagai usaha untuk mempertahankan independensi auditor. Auditor switching dapat terjadi secara mandatory dan voluntary.Auditor switching secara mandatory artinya perusahaan klien dapat mengganti auditornya sesuai dengan peraturan yang telah ditetapkan oleh pemerintah, sedangkan auditor switching secara voluntary adalah pergantian auditor yang dilakukan oleh perusahaan (klien) diluar Peraturan Pemerintah.Auditor switching di Indonesia sering dilakukan secara mandatory tetapi fakta yang terjadi fenomena pergantian auditor menunjukkan adanya 
perusahaan- perusahaan yang melakukan pergantian auditor secara voluntary (Pratitis, 2012). Perusahaan yang melakukan pergantian KAP secara voluntary disebabkan karena KAP yang terdahulu bertindak konservatif dan tidak sejalan dengan kepentingan manajemen perusahaan, sehingga perusahaan melakukan pergantian KAP secara voluntary.

Menurut Nasser et.al (2006) pergantian auditor secara voluntary akan cenderung mengakibatkan peningkatan fee audit namun dilain pihak, KAP dan BAPEPAM (Badan Pengawas Pasar modal) mengganggap bahwa pergantian auditor yang dilakukan secara voluntary akan mengganggu, karena memerlukan monitoring yang berlebih serta dipercaya akan menimbulkan biaya yang besar dibanding dengan hasil yang didapat. Pihak KAP dan BAPEPAM mengharapkan adanya alasan yang jelas dari tindakan perusahaan untuk melakukan auditor switching secara voluntary (Liyani et al., 2014)

Ketika perusahaan mengganti auditor atau KAP secara voluntary maka akan menimbulkan kecurigaan investor terhadap perusahaan, dan hal tersebut akan membuat para pemakai informasi akuntansi mempertanyakan hal apa yang mendasari perusahaan melakukan voluntary auditor switching (Zulaikha dan Fitriani, 2014). Adanya regulasi yang membatasi masa perikatan audit tersebut bertujuan agar auditor dan klien tidak menciptakan ketergantungan satu sama lain, sehingga kualitas audit tetap terjaga dan menghasilkan opini audit yang objektif. Salah satu faktor yang mempengaruhi perusahan melakukan auditor switching adalah management change. Pergantian manajemen dapat ditandai dengan pergantian direksi (CEO), dimana pergantian ini diputuskan melalui RUPS (Dwiyanti dan Arifin, 2014). Menurut Wibowo (2012) menyatakan bahwa masuknya CEO baru dapat dipakai sebagai tanda bahwa kebijakan dalam bidang akuntansi maupun di bidang keuangan perlu dirubah salah satunya auditor switching.

Hartono dan Abdul (2012) Menemukan bahwa pergantian manajemen tidak menunjukkan adanya pengaruh yang signifikan terhadap auditor switching secara voluntary. Hasil penelitian tersebut bertolak belakang dengan hasil penelitian yang dilakukan oleh Agiastuti dan Suputra (2016) dan Dwiyanti dan Arifin (2014) yang menemukan bahwamanagement change berpengaruh terhadap auditor switching secara voluntary.

Faktor lain yang mempengaruhi perusahaan melakukan auditor switching adalah financial distress. Financial distress terjadi ketika perusahaan tersebut tidak dapat memenuhi kewajiban keuangannya dan terancam bangkrut (Pratini dan Astika, 2013).

Penelitian yang dilakukan oleh Mahindrayogi dan Suputra (2016) serta Putra (2014) menunjukkan bahwa financial distress tidak berpengaruh terhadap voluntary auditor switching, sedangkan penelitian yang dilakukan oleh Pratini dan Astika (2013) serta Zulaikha dan Fitriani (2014) menunjukkan bahwa financial distress berpengaruh terhadap auditor switching secara voluntary.

Berdasarkan penelitian terdahulu, ukuran perusahaan klien juga diindikasikan sebagai salah satu faktor terjadinya auditor switching. Ukuran perusahaan klien menunjukkan seberapa besar aset yang dimiliki oleh perusahaan, semakin besar total aset sebuah perusahaan mengindikasikan bahwa ukuran perusahaan tersebut besar, begitu juga sebaliknya (Kurniyati, 2014). Penelitian yang dilakukan oleh Pradhana dan Suputra (2015) menunjukkan variabel ukuran perusahaan klien tidak berpengaruh terhadap auditor switching.

Hasil penelitian ini bertolak belakang dengan hasil penelitian yang dilakukan oleh Pradipta dan Septiani (2014) menunjukkan bahwa variabel ukuran perusahaan klien memiliki pengaruh tetapi tidak signifikan terhadap auditor switching secara voluntary.Faktor lainnya yang mempengaruhi perusahaan melakukan auditor switching adalah opini audit. Opini audit merupakan pernyataan atau pendapat yang diberikan oleh auditor terhadap laporan keuangan perusahaan untuk mengetahui tentang kewajaran laporan keuangannya (Putra, 2014). Penelitian yang dilakukan oleh Setiawan dan Aryani (2014) serta Liyani et al. (2015) menunjukkan bahwa variabel opini audit tidak berpengaruh terhadap auditor switching secara voluntary. Hasil penelitian tersebut bertolak belakang dengan penelitian yang dilakukan oleh Putra (2014) yang menunjukkan hasil bahwa opini audit berpengaruh terhadap auditor switching secara voluntary.

Berdasarkan penelitian sebelumnya terdapat hasil penelitian yang tidak konsisten dari variabel mangement change, financial distress, ukuran 
perusahaan klien dan opini audit terhadap auditor switching. Perusahaan yang dijadikan sampel penelitian ini adalah perusahaan perbankan yang terdaftar di BEI. Tujuan penelitian ini dilakukan pada perusahaan perbankan dikarenakan pergantian auditor (KAP) secara voluntary banyak dilakukan oleh perusahaan di Indonesia. Hal ini dibuktikan dengan adanya data yang menunjukkan bahwa sebanyak 23 dari 37 perusahaan perbankan yang terdaftar di BEI selama tahun 2004-2011 tercatat melakukan pergantian auditor secara voluntary. Hal ini berarti bahwa lebih dari $50 \%$ perusahaan perbankan yang terdaftar di BEI tahun 2004-2011 melakukan pergantian auditor (KAP) di luar ketentuan Peraturan Pemerintah yang berlaku (Aprilia, 2013).

Berdasarkan latar belakang yang telah diuraikan sebelumnya, maka penulis tertarik untuk meneliti permasalahan tersebut dengan judul "Pengaruh Management Change, Financial Distress, Ukuran Perusahaan Klien, dan Opini Audit terhadap Auditor Switching pada Perusahaan Perbankan yang Terdaftar di Bursa Efek Indonesa Tahun 2010-2015".

\section{Kerangka Teoritis dan pengembangan Hipotesis}

\section{Pengaruh Management Change terhadap Auditor Switching}

Pergantian manajemen disebabkan karena keputusan RUPS atau pihak manajemen berhenti karena kemauan sendiri sehinggga pemegang saham harus mengganti manejemen yang baru yaitu direktur utama atau CEO (Pradana dan Suputra, 2015). Pergantian manajemen pada sebuah perusahaan akan mempengaruhi kebijakan dalam bidang akuntansi maupun di bidang keuangan, dalam memilih Kantor Akuntan Publik (Pratini dan Astika, 2013).Pergantian manajemen dapat diikuti oleh pergantian KAP dikarenakan KAP dituntut untuk mengikuti kehendak manajemen, seperti kebijakan akuntansi yang dipakai oleh manajemen. Wibowo (2012) menyatakan bahwa masuknya CEO baru dapat dipakai sebagai tanda bahwa kebijakan-kebijakan lama perlu dirubah. Dengan adanya pergantian pada manajemen, kemungkinan akan terjadi perubahan penerbitan kebijakan, salah satunya auditor switching. Berdasarkan hasil penelitian yang dilakukan oleh Hudaib and Cooke (2006), dan Sinarwati (2010) menemukan bahwa pergantian manajemen berpengaruh pada pergantian auditor.

\section{Pengaruh Financial Distress terhadap Auditor Switching}

Financial distress merupakan keadaan dimana perusahaan mengalami kesulitan keuangan. Perusahaan yang mengalami financial distress memiliki dorongan kuat untuk melakukan pergantian auditor. Hal ini disebabkan karena kondisi perusahaan klien yang terancam bangkrut cenderung meningkatkan evaluasi subjektifitas dan kehati-hatian auditor sehingga dalam kondisi ini perusahaan cenderung untuk melakukan auditor switching secara voluntary. Auditor switching juga bisa disebabkan karena perusahaan sudah tidak memiliki kemampuan untuk membayar fee audit yang dibebankan oleh KAP yang disebabkan penurunan kemampuan keuangan perusahaan (Kurniaty, 2014).Kesulitan keuangan (financial distress) yang dialami perusahaan terjadi ketika perusahaan tersebut tidak dapat memenuhi kewajiban keuangannya dan terancam bangkrut (Pratini dan Astika, 2013).

Menurut penelitian yang dilakukan oleh Dwiyanti dan Arifin (2014), dan Agiastuti dan Suputra (2016)mendapatkan hasil bahwa financial distress berpengaruh secara signifikan dengan arah hubungan positif terhadap auditor switching dimana semakin tinggi tingkat kesulitan keuangan yang dialami suatu perusahaan dapat mendorong perusahaan tersebut untuk melakukan pergantian auditor dibandingkan dengan perusahaan lain yang tingkat kesulitan keuangan yang lebih rendah.

\section{Pengaruh Ukuran Perusahaan Klien terhadap Auditor Switching}

Ukuran perusahaan klien menunjukkan seberapa besar aset yang dimiliki oleh perusahaan, semakin besar total aset sebuah perusahaan mengindikasikan bahwa ukuran perusahaan tersebut besar, begitu juga sebaliknya (Kurniyati, 2014). Ukuran KAP harus sesuai dengan ukuran perusahaan klien, karena ketidaksesuaian ukuran antara perusahaaan klien dan ukuran KAP dapat menyebabkan berakhirnya keterlibatan audit, yaitu auditor switching (Hudaib dan Cooke, 2005). Nazri et al. (2012) berpendapat bahwa ketika perusahaan telah meningkatkan ukuran perusahaan akan menyebabkan 
meningkatnya kesulitan bagi pemilik dalam memantau tindakan manajer sebagai prinsipal, dan agen menjadi lebih jauh.

Konsekuensinya, tingkat biaya agensi juga akan meningkat dan perusahaan mungkin membutuhkan auditor yang baru dengan kualitas yang lebih tinggi untuk menyediakan pemantauan yang lebih baik. Berdasarkan hasil penelitian yang dilakukan oleh Kurniaty (2014), Juliantari dan Rasmini (2013) menunjukkan bahwa ukuran perusahaan klien berpengaruh terhadap auditor switching. Semakin besar ukuran suatu perusahaan semakin besar kemungkinan sebuah perusahaan melakukan voluntary auditor switching.

\section{Pengaruh Opini Audit terhadap Auditor Switching}

Opini audit adalah pernyataan atau pendapat yang diberikan oleh auditor. Pernyataan dan pendapat tersebut diberikan agar perusahaan mengetahui tentang kewajaran laporan keuangannya. Menurut Kawijaya dan Januarti (2002) bahwa opini selain WTP cenderung tidak disukai oleh klien. Klien lebih menginginkan auditor memberi opini WTP atas laporannya. Opini audit memberikan informasi yang bermamfaat bagi pengguna laporan keuangan eksternal karena bermamfaat untuk keputusan investasi.

Opini audit juga sering digunakan sebagai alasan oleh manajemen untuk mengganti KAP. Kondisi ini muncul ketika perusahaan klien tidak setuju dengan opini audit sebelumnya atau opini audit yang akan datang. Permasalahan ini dapat memicu salah satu pihak untuk memisahkan diri (Calderon and Ofobike, 2008).

Secara umum, klien tentu menginginkan laporan keuangannya mendapat opini wajar tanpa pengecualian dari KAP yang disewanya. Berdasarkan hasil penelitian yang dilakukan oleh Calderon dan Ofobike, 2008), Hudaib and Cooke (2006), Sudewa (2012), menyatakan bahwa opini audit berpengaruh pada pergantian auditor. Berdasarkan uraian yang telah dijelaskan mengenai pengaruh antara variabel independen dengan variabel dependen, maka skema kerangka pemikiran tentang pengaruh management change, financial distress, ukuran perusahaan klien, dan opini audit terhadap auditor switchingdapat dilihat pada Tabel 2.1.

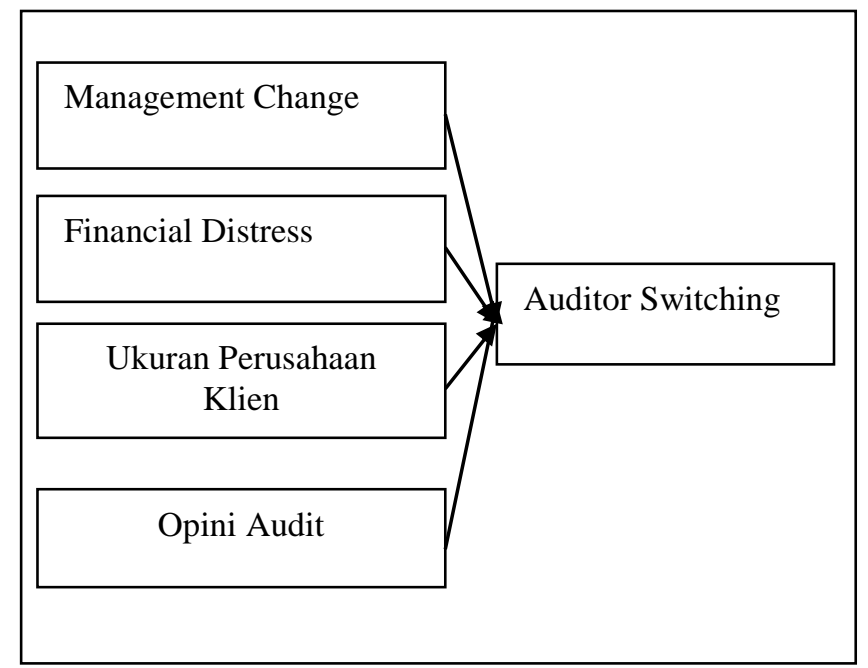

Gambar 2.1 Kerangka Pemikiran Penelitian

\section{Hipotesis}

H1: Management change, financial distress, ukuran perusahaan klien dan opini audit secara bersama-sama berpengaruh terhadap auditor switching.

$\mathrm{H} 2$ : Management change berpengaruh terhadap auditor switching.

H3: Financial distress berpengaruh terhadap auditor switching

H4: Ukuran perusahaan klien berpengaruh terhadap auditor switching.

H5: Opini audit berpengaruh terhadap auditor Switching

\section{Metode Penelitian}

\section{Desain Penelitian}

Menurut Sekaran dan Bougie (2013:95) desain penelitian merupakan bagan (blueprint) untuk pengumpulan, pengukuran, dan analisis data berdasarkan pada permasalahan studi penelitian. Desain dalam penelitian ini menggunakan metode penelitian kuantitatif. Menurut Sugiyono (2012:23) metode penelitian kuantitatif terdiri dari angka-angka dan analisis menggunakan statistik. Menurut Uma Sekaran (2013:94) desain penelitian atau rancangan suatu penelitian harus memiliki 6 (enam) aspek:

Desain penelitian, yang meliputi serangkaian pilihan pengambilan keputusan rasional, isu-isu yang berkaitan dengan keputusan mengenai tujuan studi (eksploratif, deskriptif, pengujian hipotesis), letaknya (yaitu konteks studi), jenis yang sesuai untuk penelitian (jenis investigasi), tingkat manipulasi dan kontrol peneliti (tingkat intervensi peneliti), aspek 
temporal (horizon waktu), dan level analisis data (unit analisis), adalah integral pada desain penelitian.

Tujuan studi yang dilakukan dalam penelitian ini adalah pengujian hipotesis (hypotesis testing) yang telah dirumuskan berdasarkan teori-teori dan penelitian terdahulu. Pengujian hipotesis yang dilakukan adalah menguji pengaruh dari variabel management change, financial distress, ukuran perusahaan klien, dan opini audit terhadap auditor switching

Jenis investigasi dalam penelitian ini yaitu penelitian verifikatif. Penelitian verifikatif adalah penelitian yang menjelaskan hubungan kausal antar variabel melalui pengujian hipotesis

Tingkat intervensi dalam penelitian ini yaitu intervensi minimal. Situasi studi dalam penelitian ini adalah situasi tidak diatur. Penelitian ini merupakan penelitian studi lapangan (field study).

Unit analisis yang digunakan dalam penelitian ini yaitu perusahaan perbankan yang terdaftar di BEI. Data yang dikumpulkan yaitu berupa laporan keuangan dan laporan tahunan pada perusahaan perbankan yang terdaftar di BEI selama periode 20102015.

Horizon waktu yang digunakan dalam penelitian ini adalah pooled atau panel data. Panel data adalah gabungan dari time series dan cross sectional dimana studi ini mengambil sampel pada beberapa perusahaan dan beberapa waktu yang berbeda (Gujarati, 2003:636).

\section{Populasi dan Sampel Penelitian}

Menurut Sekaran dan Bougie (2013:24) populasi mengacu pada seluruh kelompok orang, peristiwa, atau hal-hal yang menarik peneliti untuk menyelidiki, sedangkan sampel adalah bagian dari populasi. Populasi dalam penelitian ini adalah perusahaan perbankan yang terdaftar secara berturutturut di BEI tahun 2010-2015 sebanyak 30 perusahaan.

Metode yang digunakan dalam pengambilan sampel pada penelitian ini menggunakan metode purposive sampling yaitu, sampel yang memilki kriteria-kriteria tertentu. Tujuan dari penggunaan metode ini yaitu, untuk mendapatkan sampel yang sesuai dengan kriteria yang ditentukan. Kriteriakriteria untuk menentukan sampel yang digunakan dalam penelitian ini adalah:
1) Perusahaan perbankan yang terdaftar di BEI selama periode 2010-2015.

2) Perusahaan yang mempublikasikan laporan keuangan tahunnannya secara berturut-turut selama periode 2010-2015.

3) Perusahaan menyajikan informasi yang lengkap pada annual report yang berupa informasi KAP, nama CEO dan laporan auditor independen.

4) Perusahaan melakukan auditor switching paling sedikit 2 (dua) kali selama periode penelitian.

5) Laporan keuangan disajikan dalam mata uang rupiah.

Berdasarkan Kriteria tersebut, jumlah sampel yang digunakan dalam penelitian ini dapat dilihat pada tabel 3.1

Tabel 3.1

Kriteria Sampel Penelitian

\begin{tabular}{|c|l|c|}
\hline $\begin{array}{c}\mathrm{N} \\
\mathrm{o}\end{array}$ & \multicolumn{1}{|c|}{ Kriteria Sampel } & Jumlah \\
\hline 1. & $\begin{array}{l}\text { Perusahaan perbankan yang terdaftar berturut- } \\
\text { turut di BEI selama periode 2010-2015 }\end{array}$ & 30 \\
\hline 2. & $\begin{array}{l}\text { Perusahaan tidak dapat diakses laporan } \\
\text { tahunannya di BEI }\end{array}$ & $(2)$ \\
\hline 3. & $\begin{array}{l}\text { Perusahaan yang tidak menyajikan laporan } \\
\text { keuangan secara lengkap }\end{array}$ & $(13)$ \\
\hline 4. & $\begin{array}{l}\text { Perusahaan yang tidak melakukan pergantiaan } \\
\text { auditor dan KAP }\end{array}$ & $(1)$ \\
\hline 5. & $\begin{array}{l}\text { Laporan keuangan yang tidak disajikan dalam } \\
\text { mata uang rupiah }\end{array}$ & $(0)$ \\
\hline Jumlah sampel per tahun & 14 \\
\hline Jumlah observasi : 14x6 & 84 \\
\hline
\end{tabular}

Sumber data diolah (2016)

\section{Sumber dan Teknik Pengumpulan Data}

Jenis data yang digunakan dalam penelitian ini adalah data sekunder yang berupa laporan keuangan perusahaan perbankan yang terdaftar di BEI tahun 2010-2015. Data sekunder yaitu data yang data yang sudah ada dan tidak perlu dikumpulkan oleh peneliti (Sekaran dan Bougie, 2013:36). Metode pengumpulan data dalam penelitian ini yaitu metode dokumentasi.

Metode ini dilakukan dengan cara menyalin dan mengarsipkan data-data yang diperoleh dari sumbersumber yang tersedia. Data sekunder ini diperoleh dari situs resmi Bursa Efek indonesia di (www.idx.co.id). Selain itu, data sekunder lainnya diperoleh dari artikel, jurnal dan literatur lainnya yang berkaitan dengan penelitian ini. 


\section{Operasionalisasi Variabel}

\section{Variabel Dependen (Y)}

Menurut Sekaran dan Bougie (2013:68) variabel dependen yaitu variabel yang menjadi perhatian utama pada penelitian. Variabel dependen dalam penelitian ini adalah Voluntary auditor switching. VoluntaryAuditor switching merupakan tindakan yang dilakukan oleh perusahaan untuk mengganti auditor maupun mengganti kantor KAP secara sukarela tanpa ada peraturan yang mewajibkan sebuah perusahaan untuk mengganti auditornya.

Auditor switching merupakan variabel dummy. Variabel dummy adalah variabel yang memiliki dua atau lebih tingkat yang berbeda, yang diberi kode 0 atau 1 (Sekaran dan Bougie, 2013:318).Jika perusahaan melakukan voluntary auditor switching selama masa penelitian maka akan diberikan nilai 1 , sedangkan perusahaan yang tidak melakukan voluntaryauditor switching diberikan nilai 0 .

\section{Variabel Independen $(\mathrm{X})$ \\ Management Change}

Management changemerupakan tindakan yang dilakukan perusahaan untuk menganti CEO atau dewan direksi yang diputuskan melalui RUPS. Pergantian CEO ataupun dewan direksi disebabkan oleh kemauan dari diri sendiri ataupun diberhentikan oleh manajemen perusahaan.

Pergantian manajemen mengakibatkan perubahan dalam bidang akuntansi maupun dalambidang keuangan. Pegantian manajemen biasanya ditandai dengan bergantinya CEO yang lama dengan CEO yang baru. Variabel pergantian manajemen diukur menggunakan variabel dummy. Jika sebuah perusahaan melakukan pergantian CEO akan diberi kode 1 dan jika perusahaan tidak melakukan auditor switching maka diberikan nilai 0 (Chadegani et al., 2011).

\section{Financial Distress}

Financial distress merupakan kondisi keuangan perusahaan yang sedang mengalami kesulitan keuangan atau keadaan dimana perusahaan tidak dapat memenuhi kewajiban finansialnya atau perusahaan tidak dapat membayar utang jangka panjangnya kepada debitur. Financial distress biasanya diukur dengan menggunakan Debt to Asset Ratio (DAR).
Semakin tinggi proporsi debt to asset ratio, maka semakin besar juga resiko keuangan bagi kreditor maupun pemegang saham. Tingkat rasio DAR yang aman yaitu 50\%. Apabila rasio DAR melebihi $50 \%$ maka, dapat di indikasikan sebagai memburuknya kinerja keuangan sehingga perusahaan akan mengalami kesulitan keuangan (Zulaikha dan Fitriani, 2014). Financial distress dapat dirumuskan sebagai berikut:

$$
\text { DAR }=\frac{\text { Total Hutang }}{\text { Total Asset }}
$$

Keterangan:

$\mathrm{DAR}=$ Debt to Asset Ratio

\section{Ukuran Perusahaan Klien}

Ukuran perusahaan klien merupakan suatu skala yang mengklasifikasikan besar kecilnya perusahaan yang berhubungan dengan finansial perusahaaan. Ukuran perusahaan menunjukan seberapa besar aset yang dimilki perusahaan. Perusahaan besar diyakini dapat menyelesaikan kesulitan-kesulitan keuangan yang dihadapinya daripada perusahaan kecil.

Seiring dengan pertumbuhan ukuran perusahaan akan membuat prinsipal semakin sulit dalam memantau tindakan agen, yang kemungkinan cenderung memaksimalkan keuantungan diri sendiri daripada keuntungan prinsipal. Ukuran perusahaan klien diukur dengan log natural dari total aset perusahaan (Nasser et al., 2006).

Dengan rumus:

$$
\text { Size }=\text { Ln total asset }
$$

Keterangan:

Size : ukuran perusahaan klien

Ln : logaritma natural

\section{Opini Audit}

Opini audit adalah pernyataan atau pendapat yang diberikan oleh auditor terhadap laporan keuangan perusahaan (klien). Pemberian pernyataan atau pendapat tersebut diberikan agar perusahaan mengetahui tentang kewajaran dari laporan keuangannya. Ketika sebuah perusahaan memperoleh opini WTP, perusahaan tersebut cenderung untuk tidak mengganti auditornya sampai batas waktu yang telah ditetapkan pemerintah untuk melakukan pergantian auditor. Pemberian opini selain dari WTP, perusahaan atau klien akan lebih cendeung mengganti auditornya. Opini audit diukur dengan variabel dummy, jika 
perusahaan klien menerima selain opini wajar tanpa pengecualian (unqualified opinion) maka diberikan nilai 1, sedangkan jika perusahaan klien menerima opini wajar tanpa pengecualian 0 (Zulikha dan Fitriani, 2014).

\section{Hasil dan Pembahasan Statistik Deskriptif}

Statistik deskriptif memberikan gambaran mengenai karakteristik variabel yang diamati. Statistik deskriptif variabel yang digunakan dalam penelitian ini dapat dilihat pada Tabel 4.1.

\section{Tabel 4.1}

Statistik Deskriptif

Descriptive Statistics

\begin{tabular}{|c|c|c|c|c|c|}
\hline & $\mathrm{N}$ & Minimum & $\begin{array}{c}\text { Maximu } \\
\mathrm{m}\end{array}$ & Mean & $\begin{array}{c}\text { Std. } \\
\text { Deviation }\end{array}$ \\
\hline AS & 84 & 0 & 1 &, 46 &, 502 \\
MC & 84 & 0 & 1 &, 30 &, 460 \\
FD & 84 &, 75 & 1,17 &, 8951 &, 05608 \\
LnTA & 84 & 14,26 & 30,46 & 19,5288 &, 45484 \\
OA & 84 & 0 & 1 &, 50 &, 503 \\
Valid N & 84 & & & & \\
(listwise) & & & & & \\
\hline
\end{tabular}

Sumber: Output SPSS 23 (2017)

Berdasarkan Tabel 4.1 dapat dilihat nilai terendah, tertinggi, rata-rata, dan standar deviasi untuk masing-masing variabel dengan jumlah sampel penelitian yang digunakan sebanyak 84 data observasi. Auditor switching yang diproksikan dengan AS merupakan variabel dependen, sedangkan variabel independen yaitu MC (management change), FD (financial distress), LnTA (ukuran perusahaan klien), dan OA (opini audit).

Variabel dependen yaitu auditor switching yang diproksikan berdasarkan perusahaan yang melakukan auditor switching atau perusahaan yang tidak melakukan auditor switching. Nilai terendah sebesar 0 artinya perusahaan tidak melakukan auditor switching dan nilai tertinggi sebesar 1 artinya perusahaan melakukan auditor switching. Nilai rata-rata sebesar 0,46 yang berarti bahwa rata-rata nilai auditor switching yang dilakukan perusahaan perbankan yang terdaftar di BEI tahun 2010-2015 sebesar 46\%, sedangkan standar deviasi sebesar 0,502. Nilai ratarata yang lebih besar dari nilai standar deviasinya mengidentifikasikan bahwa standar error dari variabel tersebut kecil.

Variabel independen yang pertama adalah management change diproksikan berdasarkan diganti atau tidaknya CEO pada perusahaan tersebut. Nilai terendah 0 artinya perusahaan tidak melakukan pergantian CEO dan nilai tertinggi 1 artinya perusahaan melakukan pergantian CEO. Nilai rata-rata sebesar 0,30 dengan standar deviasi sebesar 0,460.

Variabel independen yang kedua adalah financial distress yang diproksikan dengan debt to asset ratio (DAR). Nilai terendah yang diperoleh sebesar 0,75 terjadi pada Bank QNB Indonesia Tbk (BKSW) pada tahun 2011. Nilai tertinggi sebesar 1,17 terjadi pada Bank Negara Indonesia (Persero) Tbk (BBNI) pada tahun 2013. Nilai rata-rata financial distress sebesar 0,8951 dengan standar deviasi sebesar 0,5608 .

Variabel ketiga adalah ukuran perusahaan klien yang diproksikan berdasarkan logaritma natural dari total asset (LnTA). Nilai terendah yang diperoleh sebesar 14,26 terjadi pada Bank Pundi Indonesia Tbk (BEKS) pada tahun 2010. Nilai tertinggi sebesar 30,46 terjadi pada Bank Artha Graha International Tbk (INPC) tahun 2010. Nilai rata-rata ukuran perusahaan klien sebesar 19,5288 dengan standar deviasi sebesar 0,45484 .

Variabel keempat adalah opini audit yang diproksikan berdasarkan opini yang diberikan oleh auditor kepada perusahaan. Nilai terendah sebesar 0 artinya perusahaan mendapatkan opini wajar tanpa pengecualian (unqualified) dan tertinggi sebesar 1 artinya perusahaan mendapat opini selain unqualified. Nilai rata-rata sebesar 0,50 dengan standar deviasi sebesar 0,503.

\section{Menilai Keseluruhan Model (Overall Model Fit)}

Sebagaimana yang telah dikemukakan sebelumnya, analisis pertama yang dilakukan adalah menilai overall model fit terhadap data. Hipotesis yang digunakan untuk menilai overall model fit adalah:

$\mathrm{H}_{0}$ : Model yang dihipotesiskan fit dengan data $\mathrm{H}_{\mathrm{a}}$ : Model yang dihipotesiskan tidak fit dengan data

Pengujian dilakukan dengan membandingkan nilai antara -2 log likelihood (-2LL) pada awal (blok number $=0)$ dengan nilai -2 log likelihood $(-2 \mathrm{LL})$ pada akhir (block number $=1$ ). Pengurangan nilai antara - 
2LL awal dengan -2LL akhir menunjukkan bahwa model dihipotsiskan fit dengan data (Ghozali,2011:340). Perbandingan nilai -2LL awal dengan -2LL akhir dapat dilihat pada Tabel 4.2.

Tabel 4.2

Menilai Keseluruhan Model (Overall model fit) Iteration History $\mathbf{a}^{\mathrm{a}, \mathrm{b}, \mathrm{c}, \mathrm{d}}$

\begin{tabular}{|c|c|c|c|c|c|c|}
\hline \multirow[b]{2}{*}{ Iteration } & \multirow{2}{*}{$\begin{array}{c}-2 \log \\
\text { likeliho } \\
\text { od }\end{array}$} & \multicolumn{5}{|c|}{ Coefficients } \\
\hline & & $\begin{array}{c}\text { Consta } \\
n t\end{array}$ & MC & FD & LnTA & $\mathrm{OA}$ \\
\hline Ste 1 & 111,643 & 4,424 &, 355 & $-6,489$ &, 051 & ,296 \\
\hline 12 & 111,572 & 5,396 & ,358 & $-7,675$ &, 054 & ,308 \\
\hline 3 & 111,572 & 5,449 & ,357 & $-7,739$ &, 054 & ,308 \\
\hline 4 & 111,572 & 5,450 & ,357 & $-7,739$ &, 054 & ,308 \\
\hline
\end{tabular}

a. Method: Enter

b. Constant is included in the model.

c. Initial -2 Log Likelihood: 116,020

d. Estimation terminated at iteration number 4 because parameter estimates changed by less than ,001.

Berdasarkan Tabel 4.2 menunjukkan bahwa nilai awal likelihood adalah sebesar 116,020, setelah dimasukkan keempat variabel independen yaitu management change, financial distress, ukuran perusahaan klien, dan opini audit ke dalam model, maka nilai -2LL akhir mengalami penurunan angka menjadi 111,572. Penurunan nilai likelihood -2LL ini dapat diartikan bahwa penambahan variabel bebas ke dalam model menunjukkan bahwa model regresi yang lebih baik sehingga model yang dihipotesiskan fitdengan data atau dengan kata lain $\mathrm{H}_{0}$ diterima. Hasil perhitungan pada Tabel 4.2 diatas secara lengkap dapat dilihat pada lampiran 8 .

\section{Menguji Kelayakan Model Regresi}

Analisis selanjutnya adalah menguji kelayakan model regresi logistik yang akan digunakan. Pengujian kelayakan model regresi logistik dilakukan dengan menggunakan Goodness of Fit Test yang diukur dengan nilai Chi-Square. Jika nilai signifikansi ChiSquare sama dengan atau kurang dari 0,05, maka hipotesis nol ditolak yang berarti ada perbedaan signifikan antara model dengan nilai observasinya sehingga Goodness of Fit Test tidak baik karena model tidak dapat memprediksi nilai obeservasinya atau dapat dikatakan model dapat diterima karena cocok dengan data observasinya. Hasil pengujian kelayakan model regresi dapat dilihat pada Tabel 4.3

Tabel 4.3

\section{Hosmer and Lemeshow Test}

\begin{tabular}{|c|c|c|c|}
\hline Step & Chi-square & Df & Sig. \\
\hline 1 & 4,763 & 8 &, 783 \\
\hline
\end{tabular}

Berdasarkan Tabel 4.3 menunjukkan hasil pengujian hosmer and lemeshow, dengan probabilitas signifikansi menunjukkan angka 0,783. Nilai signifikansi dengan probabilitas ini lebih besar dari 0,05 sehingga $\mathrm{H}_{0}$ diterima. Hal ini berarti bahwa model regresi layak untuk digunakan dalam analisi selanjutnya, karena tidak ada perbedaan yang nyata antara klasifikasi yang diprediksi dengan klasifikasi yag diamati, dengan kata lain model regresi mampu memprediksi nilai observasinya. Hasilnya perhitungan pata Tabel 4.3 diatas secara lengkap dapat dilihat pada lampiran 8.

\section{Koefisien Determinasi}

Koefisien determinasi digunakan untuk mengetahui seberapa besar variabilitas variabelvariabel independen mampu memperjelas variabilitas variabel dependen. Koefisien determinasi pada regresi logistik dapat dilihat pada nilai Nagelkerke $R$ Square. Nilai Nagelkerke $R$ square dapat diinterpretasikan seperti nilai $R$ square pada regresi berganda (Ghozali, 2011:341). Nilai ini di dapat dengan cara membagi nila cox\&Snell $R$ Square dengan nilai maksimumnya. Nilai Nagelkerke $R$ Square dapat dilihat pada Tabel 4.4.

Tabel 4.4

Nagelkerke R Square

\begin{tabular}{|l|l|l|l|}
\hline Step & $\begin{array}{l}-2 \text { Log } \\
\text { likelihood }\end{array}$ & $\begin{array}{l}\text { Cox \& Snell } \\
\text { R Square }\end{array}$ & $\begin{array}{l}\text { Nagelkerke } \\
\text { R Square }\end{array}$ \\
\hline 1 & $111,572^{\text {a }}$ &, 052 &, 269 \\
\hline
\end{tabular}

a. Estimation terminated at iteration number 4 because parameter estimates changed by less than, 001 .

Berdasarkan Tabel 4.4 tersebut menunjukkan nilai Nagelkerke R Square sebesar 0,269. Hal ini menunjukkan bahwa variabilitas variabel dependen dapat dijelaskan oleh variabel independen adalah sebesar $26,9 \%$ dan sisanya yaitu $73,1 \%$ dijelaskan oleh variabilitas variabel-variabel lain diluar model 
penelitian. Hasil perhitungan pada Tabel 4.4 diatas secara lengkap disajikan pada lampiran 8.

\section{Tabel Klasifikasi}

Tabel klasifikasi akan menunjukkan kekuatan prediksi dari model untuk memprediksi kemungkinan perusahaan melakukan auditor switching yang ditunjukkan pada tabel klasifikasi sebagaimana ditampilkan pada Tabel 4.5.

Tabel 4.5

Tabel Klasifikasi

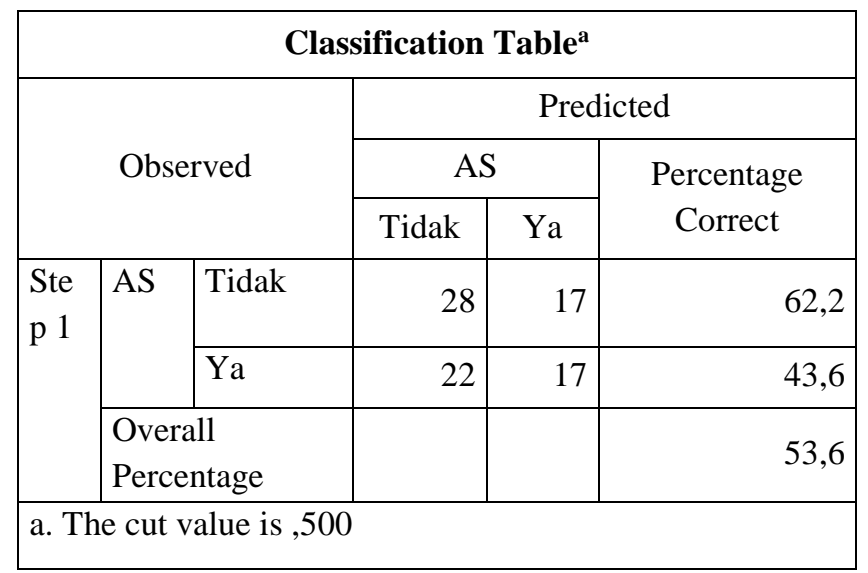

Berdasarkan Tabel 4.5 Matrik klasifikasi menunjukkan kekuatan prediksi dari model regresi untuk memprediksi kemungkinan perusahaan melakukan auditor switching adalah sebesar 43,6\%. Hal ini menunjukkan bahwa dengan menggunakan model regresi yang digunakan, terdapat sebanyak 17 perusahaan yang melakukan auditor switching dari total 39 perusahaan yang melakukan auditor switching. Kekuatan prediksi model perusahaan yang tidak melakukan auditor switching adalah sebesar $62,2 \%$, yang berarti bahwa dengan model regresi yang digunakan ada sebanyak 28 perusahaan $(62,2 \%)$ yang diperediksi tidak melakukan auditor switching dari total 45 perusahaan yang tidak melakukan auditor switching. Hasil perhitungan pada Tabel 4.5 diatas secara lengkap dapat dilihat pada lampiran 8 .

\section{Hasil Pengujian Hipotesis}

Pengujian hipotesis dalam penelitian ini bertujuan untuk menguji pengaruh management change, financial distress, ukuran perusahaan klien, dan opini audit terhadap auditor switching dengan menggunakan analisis regresi logistik. Analisis regresi logistik ini digunakan untuk mendapatkan nilai nilai koefisien logit dengan koefisien determinasi yang sesungguhnya.

Koefisien regresi logit digunakan untuk menguji pengaruh variabel independen, secara parsial terhadap variabel dependen, sedangkan untuk mengetahui besarnya (kuat-lemahnya) pengaruh variabel independen terhadap variabel dependen, baik secara bersama-sama maupun secara parsial ditunjukkan oleh koefisien determinasi.

Dengan kata lain, koefisien determinasi digunakan untuk mengetahui seberapa besar (dalam persen) variabel independen, baik secara bersamasama maupun secara parsial dapat menjelaskan variabel dependen.Berdasarkan hasil perhitungan dengan menggunakan program SPSS versi 23, hasil regresi logistik secara lengkap dapat dilihat padalampiran 8.Ringkasan hasil pengujian hipotesis dapat dilihat pada Tabel 4.6

Tabel 4.6

Hasil Pengujian Hipotesis Variables in the Equation

\begin{tabular}{|c|c|c|c|c|c|c|c|c|c|}
\hline & \multirow[b]{2}{*}{ B } & \multirow[b]{2}{*}{ S.E. } & \multirow[b]{2}{*}{ Wald } & \multirow[b]{2}{*}{$\mathrm{df}$} & \multirow[b]{2}{*}{ Sig. } & \multirow[b]{2}{*}{$\operatorname{Exp}(B)$} & \multicolumn{2}{|c|}{$\begin{array}{c}\text { 95\% C.I.for } \\
\text { EXP(B) }\end{array}$} \\
\hline & & & & & & & & Lower & Upper \\
\hline \multirow{5}{*}{\multicolumn{2}{|c|}{$\begin{array}{ll}\text { St } & \text { MC } \\
\text { ep } & \\
1^{\text {a }} & \text { FD } \\
& \text { LnTA } \\
& \text { OP } \\
& \text { Constant }\end{array}$}} &, 357 & ,498 & 5,516 & 1 & ,023 & 1,430 &, 539 & 3,792 \\
\hline & & $-7,739$ & 4,921 & ,473 & 1 & ,498 & 600 & ,056 & 6,732 \\
\hline & & 054 & ,066 & 3,663 & 1 & ,046 & 1,056 & ,927 & 1,202 \\
\hline & & ,308 & 455 & 2,460 & 1 & ,002 & 1,361 &, 558 & 3,318 \\
\hline & & 5,450 & 4,462 & 1,492 & 1 &, 222 & 232,656 & & \\
\hline
\end{tabular}

a. Variable(s) entered on step 1: MC, FD, LnTA, OA.

Model Summary

\begin{tabular}{|l|c|r|r|}
\hline Step & $\begin{array}{c}-2 \text { Log } \\
\text { likelihood }\end{array}$ & $\begin{array}{c}\text { Cox \& } \\
\text { Snell R } \\
\text { Square }\end{array}$ & Nagelkerke R Square \\
\hline 1 & $111,572^{\mathrm{a}}$ &, 052 &, 269 \\
\hline
\end{tabular}

a. Estimation terminated at iteration number 4 because parameter estimates changed by less than , 001 .

$\mathrm{H}_{1}:$ Management change, financial distress, ukuran perusahaan klien, dan opini audit secara bersama-sama berpengaruh terhadap auditor switching pada perusahaan perbankan yang terdaftar di Bursa Efek Indonesia.

Management change, financial distress, ukuran perusahaan klien, dan opini audit secara bersama-sama 
berpengaruh terhadap auditor switching ditunjukkan oleh nilai koefisien regresi logit yang tidak sama dengan nol $(\beta \neq 0)$, sehingga dapat dinyatakan bahwa managemant change, financial distress, ukuran perusahaan klien, dan opini audit secara bersama-sama berpengaruh terhadap auditor switching. Besarnya pengaruh management change,financial distress, ukuran perusahaan klien, dan opini audit secara bersama-sama terhadap auditor switching adalah 26,9\%. Hal ini ditunjukkan oleh nilai Nagelkerke's $R$ Square sebesar $73.1 \%$ di pengaruhi oleh variabel lain yang tidak dimasukkan ke dalam penelitian.

$\mathrm{H}_{2}$ : Managemnet change berpengaruh terhadap auditor switching pada perusahaan perbankan yang terdaftar di Bursa Efek Indonesia.

Berdasarkan Tabel 4.6, hasil penelitian terhadap management change menunjukkan bahwa nilai Wald, dengan nilai signifikansi sebesar 0,023 (lebih kecil dari 0,05) maka $\mathrm{H}_{2}$ diterima. Dengan demikian, hasil perhitungan statistik menunjukkan bahwa secara parsial variabel management change berpengaruh signifikansi terhadap auditor switching.

$\mathrm{H}_{3}$ : Financial distress berpengaruh terhadap auditor switching pada perusahaan perbankan yang terdaftar di Bursa Efek Indonesia.

Berdasarkan Tabel 4.6, hasil penelitian terhadap financial distress menunjukkan bahwa nilai Wald dengan nilai signifikansi sebesar 0,498 (lebih besar dari 0,05$)$ maka $\mathrm{H}_{3}$ ditolak. Dengan demkian, hasil perhitungan statistik menunjukkan bahwa secara parsial financial distress tidak berpengaruh signifikan terhadap auditor switching.

$\mathrm{H}_{4}$ : Ukuran perusahaan klien berpengaruh terhadap auditor switching pada perusahaan perbankan yang terdaftar di Bursa Efek Indonesia.

Berdasarkan Tabel 4.6, hasil penelitian terhadap ukuran perusahaan klien menunjukkan bahwa nilai Wald, dengan nilai signifikansi sebesar 0,046 (lebih kecil dari 0,05) maka $\mathrm{H}_{4}$ diterima. Dengan demikian, hasil perhitungan statistik menunjukkan bahwa secara parsial variabel ukuran perusahaan berpengaruh signifikan terhadap auditor switching.

$\mathrm{H}_{5}$ : Opini audit berpengaruh terhadap auditor switching pada perusahaan perbankan yang terdaftar di Bursa Efek Indonesia.

Berdasarkan Tabel 4.6, hasil penelitian terhadap opini audit menunjukkan bahwa nilai Wald, dengan nilai signifikansi sebesar 0,002 (lebih kecil dari 0,05) maka $\mathrm{H}_{5}$ diterima. Dengan demikian, hasil perhitungan statistik menunjukkan bahwa secara parsial variabel opini audit berpengaruh signifikan terhadap auditor switching.

Dari pengujian dengan regresi logistik, diperoleh persamaan sebagai berikut:

\section{SWITCH = $5,450+0,357 \mathrm{X}_{1}-7,739 \mathrm{X}_{2}+0,054 \mathrm{X}_{3}+0,308 \mathrm{X}_{4}+\varepsilon$}

Dari persamaaan regresi diatas dapat dijelaskan bahwa:

1. Variabel konstan model regresi logistik mempunyai koefisien positif sebesar 5,450 yang berarti jika variabel lain dianggap konstan maka auditor switching mengalami kenaikan sebesar 5,450 .

2. Koefisien regresi management change yang dinotasikan dengan $\mathrm{X}_{1}$ adalah sebesar 0,357, artinya setiap $100 \%$ kenaikan pada variabel management change maka auditor switching yang dilakukan oleh perusahaan akan meningkat sebesar 53,7\% dengan asumsi variabel variabel independen lain dalam model dianggap konstan.

3. Koefisien regresi financial distress yang dinotasikan dengan $\mathrm{X}_{2}$ adalah sebesar $-7,739$ artinya setiap $100 \%$ kenaikan pada financial distress akan mengalami penurunan auditor switching sebesar 773,9\% dengan asumsi variabel independen lain dalam model dianggap konstan. Hal ini berarti arah model tersebut adalah negatif.

4. Koefisien regresi ukuran perusahaan klien yang dinotasikan dengan $\mathrm{X}_{3}$ adalah sebesar 0,054, artinya setiap $100 \%$ kenaikan pada variabel ukuran perusahaan klien maka auditor switching yang dilakukan perusahaan akan meningkat sebesar 5,4\% dengan asumsi variabel independen lain dalam model dianggap konstan.

5. Koefisien regresi opini audit yang dinotasikan dengan $\mathrm{X}_{4}$ adalah sebesar 0,308 yang artinya setiap $100 \%$ kenaikan pada variabel opini audit maka auditor switching yang dilakukan oleh perusahaan akan meningkat sebesar 30,8\% dengan asumsi variabel independen lain dalam model dianggap konstan.

6. Epsilon (error term) atau $\varepsilon$ berarti bahwa ada faktor-faktor (variabel-variabel) lain yang mempengaruhi auditor switching selain 
management change, financial distress, ukuran perusahaan klien, dan opini audit

\section{Pembahasan dan Hasil Penelitian}

\section{Pengaruh Management Change terhadap Auditor Switching}

Management change ditandai dengan pergantian direksi (CEO), dimana pergantian direksi ini diputuskan melalui RUPS (Dwiyanti dan Arifin, 2014). Wibowo (2012) menyatakan bahwa masuknya CEO baru dapat dipakai sebagai tanda bahwa kebijkan dalam bidang akuntansi maupun dibidang keuangan perlu dirubah salah satunya auditor switching (Pratini dan Astika, 2013).

Berdasarkan hasil pengujian hipotesis sebelumnya, diperoleh nilai signifikansi untuk variabel management change sebesar 0,02 (lebih kecil dari $0,05)$ artinya secara parsial management change berpengaruh terhadap auditor switching. Hasil ini sejalan dengan penelitian yang dilakukan oleh Agiastuti dan Suputra (2016) dan Dwiyanti dan Arifin (2014), penelitian tersebut menyatakan bahwa management change berpengaruh signifikan terhadap auditor switching. Hal ini mengkonfirmasi bahwa pergantian direksi (CEO) yang dilakukan perusahaan cukup menentukan perusahaan untuk melakukan auditor switching.

\section{Pengaruh Financial Distress terhadap Auditor Switching}

Kondisi keuangan perusahaan yang tidak sehat dan terancam bangkrut cenderung meningkatkan evaluasi subjektivitas dan kehati-hatian auditor. Kondisi ini akan mendorong perusahaan untuk melakukan auditor switching secara voluntary (Setiawan dan Aryani, 2014). Menurut nasser et al. (2006) mendefinisikan bahwa perusahaan yang mengalami kebangkrutan akan lebih sering melakukan pergantian KAP dibandingkan perusahaan yang tidak mengalami kebangkrutan.

Berdasarkan hasil pengujian hipotesis sebelumnya, diperoleh nilai signifikansi untuk variabel financial distress sebesar 0,498 (lebih besar dari 0,05) artinya secara parsial financial distress tidak berpengaruh terhadap auditor switching. Hasil perhitungan tersebut tidak berhasil mendukung hipotesis yang diajukan, hal ini dapat disebabkan oleh biaya start up yang tinggi apabila perusahaan mengganti auditornya, sedangkan kondisi perusahaan tidak stabil. Hasil penelitian inididukung olehMahindrayogi dan Suputra (2016) serta Putra (2014). Hasil penelitian tersebut tidak mendukung adanya pengaruh financial distress terhadap auditor switching.Hasil penelitian ini tidak mendukung penelitian dari Pratini dan Astika (2013) dan Fitriani dan Zulaikha (2014) yang menunjukkan bahwa financial distress berpengaruh terhadap auditor switching.

\section{Pengaruh Ukuran Perusahaan Klien terhadap Auditor Switching}

Ukuran perusahaan klien menunjukkan seberapa besar aset yang dimiliki perusahaan, semakin besar total aset sebuah perusahaan mengindikasikan bahwa ukuran perusahaan tersebut besar, begitu juga sebaliknya (Kurniyati, 2014). Ukuran perusahaan klien harus sesuai dengan ukuran KAP, karena ketidaksesuaian tersebut dapat menyebabkan berakhirnya keterlibatan audit yaitu auditor switching.

Berdasarkan hasil pengujian hipotesis sebelumnya, diperoleh nilai signifikansi untuk variabel ukuran perusahaan klien sebesar 0,046 (lebih kecil dari $0,05)$ artinya secara parsial ukuran perusahaan klien berpengaruh terhadap auditor switching. Hasil penelitian ini sejalan dengan penelitian yang dilakukan oleh Pradipta dan Septiani (2014), penelitian tersebut menyatakan bahwa ukuran perusahaan klien berpengaruh signifikan terhadap auditor switching. Hal ini mengkonfirmasi bahwa ukuran perusahaan klien cukup menentukan perusahaan untuk melakukan auditor switching.

\section{Pengaruh Opini Audit terhadap Auditor Switching}

Perusahaan menginginkan pendapat wajar tanpa pengecualian (unqualified) atas laporan keuangannya. Ketika perusahaan menerima pendapat wajar dengan pengecualian (qualified opinion) atas laporan keuangannya maka perusahaan akan cenderung untuk menggganti auditornya. Hal ini disebabkan karena pihak manajemen perusahaan tidak setuju dengan opini yang telah diberikan auditor (Pawitri dan Ketut, 2015).

Berdasarkan hasil pengujian hipotesis sebelumnya, diperoleh nilai signifikansi untuk variabel opini audit sebesar 0,002 (lebih kecil dari 0,05) artinya secara parsial variabel opini auditberpengaruh 
terhadap auditor switching. Hal ini sejalan dengan penelitian yang dilakukan oleh putra (2014) dan Dwiyanti dan Arifin (2014), penelitian tersebut menyatakan bahwa opini audit berpengaruh signifikan terhadap auditor switching. Hal ini mengkonfirmasi bahwa opini audit yang di terima oleh perusahaan cukup menentukan perusahaan untuk melakukan auditor switching.

\section{Kesimpulan, Keterbatasan, Dan Saran Kesimpulan}

Berdasarkan hasil pengujian dan pembahasan yang telah diuraikan sebelumnya, maka dapat disimpulkan bahwa:

1. Management change, financial distress, ukuran perusahaan klien, dan opini audit berpengaruh positif terhadap auditor switching pada perusahaan perbankan yang terdaftar di Bursa Efek Indonesia tahun 2010-1015.

2. Berdasarkan hasil uji regresi logistik (logistic regression) menunjukkan bahwa management change berpengaruh signifikan terhadap auditor switching pada perusahaan perbankan yang terdaftar di Bursa Efek Indonesia tahun 20102015.

3. Berdasarkan hasil uji regresi logistik (logistic regresssion) menunjukkan bahwa financial distress tidak berpengaruh terhadap auditor switching pada perusahaan perbankan yang terdaftar di Bursa Efek Indonesia tahun 20102015.

4. Berdasarkan hasil uji regresi logistik (logistic regression) menunjukkan bahwa ukuran perusahaan klien berpengaruh signifikan terhadap auditor switching pada perusahaan perbankan yang terdaftar di Bursa Efek Indonesia tahun 2010-2015.

5. Berdasarkan hasil uji regresi logistik (logistic regression) menunjukkan bahwa opini auditberpengaruh signifikan terhadap auditor switching pada perusahaan perbankan yang terdaftar di Bursa Efek Indonesia tahun 20102015.

\section{Keterbatasan}

Penelitian ini mempunyai keterbatasanketerbatasan yang dapat dijadikan bahanpertimbangan untuk peneliti selanjutnya sehingga diharapkan untuk hasil yang lebih baik dimasa yang akan datang. Keterbatasan-keterbatasan tersebut antara lain:

1. Pada penelitian ini peneliti hanya memilih empat variabel saja yaitu management change, financial distress, ukuran perusahaan klien, dan opini audit. Variabel-variabel lain seperti fee audit, CSR, pertumbuhan perusahaan, dan pergantian komite audit yang mungkin dapat mempengaruhi perusahaan untuk melakukan auditor switching tidak diuji pada penelitian ini.

2. Objek penelitian hanya menggunakan perusahaan perbankan yang terdaftar di Bursa Efek Indonesia tahun 2010-2015, sehingga hasilnya tidak dapat digeneralisasikan untuk perusahaan-perusahaan lainnya yang terdaftar di BEI.

3. Sampel yang digunakan dalam penelitian ini relatif sedikit, yaitu hanya 14 perusahaan perbankan dan tidak semua perusahaan perbankan yang terdaftar di BEI laporan keuangannya dapat diakses.

\section{Saran}

Berdasarkan hasil pembahasan serta beberapa kesimpulan dan keterbatasan pada penelitian ini, adapun saran-saran yang dapat penulis berikan untuk mendapatkan hasil yang lebih baik, antara lain:

\section{Saran Akademis}

1. Diharapkan pada penelitian selanjutnya dapat menambahkan beberapa variabel-variabel lain seperti fee audit, CSR, pertumbuhan perusahaan dan pergantian komite audit yang mungkin dapat mempengaruhi auditor switching yang dilakukan oleh perusahaan-perusahan di Indonesia.

2. Untuk penelitian selanjutnya diharapkan untuk memperluas objek penelitian, tidak hanya pada perusahaan perbankan saja tetapi seluruh perusahaan-perusahaan yang terdaftar di Bursa Efek Indonesia.

\section{Saran Praktis}

1. Bagi perusahaan agar lebih berhati-hati dalam pengambilan keputusan untuk melakukan auditor switching.

2. Bagi Auditor agar tidak menjalin hubungan kerja terlalu lama dengan klien yang dapat menganggu independensi auditor. 
3. Bagi calon investor, sebelum berinvestasi pada sebuah perusahaan, agar terlebih dulu untuk memperhatikan laporan keuangan auditan yang diterbitkan perusahaan dengan tujuan agar calon invetstor tidak salah mengambil keputusan untuk berinvestasi pada perusahaan tersebut.

\section{Daftar Pustaka}

Agiastuti, I. P. A., \& Suputra, I. D. G. D. S. 2016. Faktor-Faktor yang berpengaruh pada Voluntary Auditor Switching. E-Journal Akuntansi Udayana, 17: 56-83.

Agusrianda., R. A. S. S., \& Safitri, D. 2014. Analisis faktor-faktor yang mempengaruhi pergantian akuntan Publik. Jurnal Online Mahasiswa, 1(2).

Andra, Ichlaisa Nurul. 2012. Faktor-Faktor yang Mempengaruhi Auditor Switching Setelah ada Kewajiban Rotasi Audit di Indonesia. Skripsi dipublikasikan. Semarang: Universitas Diponegoro.

Anthony, Robert N \& Vijay Govindarajan. 2009. Sistem Pengendalian Manajemen. Jakarta: Salemba Empat.

Aprillia, E. 2013. Analisis Faktor-Faktor yang Mempengaruhi Auditor Switching. Accounting Analysis Journal, 2(3): 199-207

Astrini, N. R., \& Muid, D. 2013. Analisis FaktorFaktor Yang Mempengaruhi Voluntary Auditor Switching Di Perusahaan Manufaktur Indonesia. Diponegoro Journal of Accounting, 3: 1-11.

Calderon, Thomas G. and Emeka Ofobike. 2008. Determinants of Clientinitiated and Auditorinitiated Auditor Changes. Managerial Auditing Journal, 23(1): 24-32.

Chadegani, A. A., Mohamed, Z. M., \& Jari, A. 2011. The Determinant Factors of Auditor Switch among Companies Listed on Tehran Stock Exchange. International Research Journal of Finance and Economics, 80(80): 158-168.

Dwiyanti, R. M. E., \& Arifin, S. 2014. Faktor-Faktor yang Mempengaruhi Auditor Switching. Diponegoro Journal of Accounting, 3: 1-8.

Ghozali, Imam. 2011. Aplikasi Analisis Multivariate dengan Program SPSS 19. Edisi Kelima. Semarang: Badan Penerbit Universitas Diponegoro.

Gujarati, D.N. 2003. Basic Econometrics. New York: McGraw Hill Book Co.
Hair, Joseph F Black, Willim C. Babin, Barry J \& Anerson, Roplh E. 2006. Multivariate Data Analisis. 6 th. New Jersey: Pearson Prentice Hall. Hartono, A. T., \& Abdul, R. 2015. Analisis Hubungan Auditor-Klien : Faktor-Faktor yang Mempengaruhi Auditor Switching Di Indonesia. Diponegoro Journal of Accounting, 4(4): 1-12.

Hudaib, M., \& Cooke, T. E. 2005. The Impact of Managing Director Changes and Financial Distress on Audit Qualification and Auditor Switching. Journal of Business Finance \& Accounting, 32(9): 1703-1739.

Institut Akuntan Publik Indonesia. 2011. Standar Profesional Akuntan Publik. Jakarta: Salemba Empat.

Johari, T. H. M., \& Hadiprajitno, P. B. 2015. Pengaruh Corporate Governance terhadap voluntary auditor switching. Diponegoro Journal of Accounting, 4: 1-14.

Juliantari, N. W. A., \& Rasmini, N. K. R. 2013. Auditor Switching Dan Faktor-Faktor yang Mempengaruhinya. E-Jurnal Akuntansi Universitas Udayana, 33: 231-246.

Kawijaya, N., dan Juaniarti. 2002. Faktor-faktor yang Mendorong Perpindahan Auditor Pada Perusahaan-perusahaan di Surabaya dan Sidoarjo. Jurnal Akuntansi \& Keuangan, 4(2): 93-105.

Kurniaty, V. 2014. Pengaruh Pergantian Manajemen, Opini Audit, Financial Distress, Ukuran KAP, dan Ukuran Perusahaan Klien terhadap Auditor Switching pada Perusahaan Real Estate dan Property di Bursa Efek Indonesia. Jurnal Online Mahasiswa, 1(2): 1-15.

Lembaran Negara Republik Indonesia. 2015. Peraturan Pemerintah Republik Indonesia Nomor 20 Tahun 2015. Tentang Praktik Akuntan Publik.

Liyani, A., P. Purnamasari, \& M. Maemunah. 2015. Pengaruh CSR, Auditor Opinion dan Financial Distress terhadap Auditor Swicthing pada Perusahaan Sektor Keuangan. Prosiding Akuntansi.

Mahindrayogi, K. T., \& Suputra, I. D. 2016. FaktorFaktor Yang Memengaruhi Voluntary Auditor Switching Pada Perusahaan Manufaktur Di Bursa Efek Indonesia. E-Jurnal Akuntansi Universitas Udayana, 3: 1755-1781. 
Menteri Keuangan. 2008. Peraturan Menteri Keuangan Nomor: 17/PMK.01/2008 tentang Jasa Akuntan Publik.

Nasser, A. T. A., Wahid, E. A., Nazri, S. N. F. S. M., \& Hudaib, M. 2006. Auditor-client relationship: the case of audit tenure and auditor switching in Malaysia. Managerial Auditing Journal, 21(7): 724-737.

Nazri, S. N. F. S. M., Smith, M., \& Ismail, Z. 2012. Factors influencing auditor change: Evidence from Malaysia.Asian Review of Accounting, 20(3): 222-240.

Pawitri, N. M. P., \& Ketut, Y. 2015. Pengaruh Audit Delay, Opini Audit, Reputasi Auditor Dan Pergantian Manajemen Pada Voluntary Auditor Switching. E-Jurnal Akuntansi Universitas Udayana, 1: 214-228.

Pratini, I. G. A. P., \& Astika, I. B. P. 2013. Fenomena Pergantian Auditor di Bursa Efek Indonesia. EJurnal Akuntansi Universitas Udayana,2: 470482.

Pradipta, P. R., \& Septiani, A. 2014. Faktor-Faktor Yang Mempengaruhi Perusahaan Auditor Secara Voluntary. Diponegoro Journal of Accounting, 3(3): 1-10.

Pradana, B. A., \& Saputra, D. 2015. Pengaruh Audit Fee, Going Concern, Financial Distress, Ukuran Perusahaan, Pergantian Manajemen Pada Pergantian Auditor. E- Jurnal Akuntansi Universitas Udayana, 3: 713-729.

Pratitis, Y. 2012. Auditor Switching: Analisis Berdasar Ukuran KAP, Ukuran Klien dan Financial Distress. Accounting Analysis Journal, 1(1): 1-4.

Putra, I. W. D. W. 2014. Pengaruh Financial Distress, Rentabilitas, Pertumbuhan Perusahaan Dan Opini Audit Pada Pergantian Auditor. E-Jurnal Akuntansi Universitas Udayana, 82: 308-323.

Sekaran, Uma \& Bougie, R. 2013. Research Methods for business. Edisi 6 Jakarta: Salemba Empat.

Setiawan, I. M. A. \& Aryani, N. K. L. 2014. Pengaruh Corporate Social Responsibility, Auditor Opinion, Financial Distress, Size Terhadap Auditor Switching. E-Jurnal Akuntansi Universitas Udayana, 2: 231-250.

Sinarwati, Ni Kadek. 2010. Mengapa Perusahaan Manufaktur yang Terdaftar di BEI melakukan Pergantian Kantor Akuntan Publik ?. Simposium Nasional Akuntansi XII, Purwokerto.
Sudewa, Oka. 2012. Pengaruh Opini Audit, Perubahan Rentabilitas, Pergantian Manajemen, Ukuran KAP, dan Financial Distress pada Pergantian Auditor. Skripsi Jurusan Akuntansi Fakultas Ekonomi dan Bisnis Universitas Udayana.

Sugiyono. 2012. Metode Penelitian Bisnis (Pendekatan Kuantitatif, Kualitatif, dan R\&D). Bandung: Alfabeta.

Wibowo. 2012. Manajemen Kinerja. Buku 1. Edisi 4. Jakarta: Rajawali Grafindo Persada.

Zulaikha, \& Fitriani, N. A. 2014. Analisis FaktorFaktor Yang Mempengaruhi Voluntary Auditor Switching Di Perusahaan Manufaktur Indonesia. Diponegoro Journal of Accounting, 3: 1-13. 